Pelestarian Kawasan Pecinan Singkawang, Provinsi Kalimantan Barat 59-69

\title{
PELESTARIAN KAWASAN PECINAN SINGKAWANG, PROVINSI KALIMANTAN BARAT ${ }^{*}$
}

\author{
Ida Bagus Putu Prajna Yogi*
} Balai Arkeologi Banjarmasin, Jalan Gotong Royong II, RT 03/06, Banjarbaru 70711, Kalimantan Selatan;
Telepon (0511) 4781716; Facsimile (0511) 4781716

Artikel masuk pada 12 Desember 2012

Artikel selesai disunting pada 26 Maret 2013

\begin{abstract}
Abstrak. Indonesia adalah negara yang lambat-laun memudar sejarah eksistensinya. Kehilangan tersebut diakibatkan oleh banyaknya bukti fisik sejarah Indonesia yang dihancurkan demi sejumlah faktor. Di antara faktor-faktor tersebut yang sering dijadikan alasan penghancuran selama empat dekade belakangan ini adalah pembangunan masyarakat yang sejahtera. Salah satu bukti fisik yang sedikit demi sedikit diabaikan kelestariannya adalah kawasan Pecinan di Kota Singkawang. Tulisan ini membahas komunitas Cina di Singkawang dalam perkembangan sejarah Indonesia dan strategi pelestarian kawasan Pecinannya. Studi tersebut dilakukan menggunakan metode deskriptif-analitis dengan penalaran induktif. Hasil studi menunjukkan bahwa komunitas Cina telah berkontribusi dalam perkembangan perekonomian di kawasan Singkawang. Dengan demikian, penciptaan kawasan Pecinan dapat diajukan sebagai salah satu strategi pelestarian sekaligus pemanfaatan cagar budaya Kota Singkawang.

Kata kunci: sejarah Singkawang, komunitas Cina, emas, peninggalan arkeologis, Singkawang, Pecinan, pengelolaan cagar budaya
\end{abstract}

Abstract. THE PRESERVATION OF PECINAN REGION OF SINGKAWANG. Indonesia's historical existence is gradually fading. Such loss is due to a number of factors which lead to the destruction of many physical evidences of Indonesia's history. Among these factors which are often used as the reason for such destruction this past four decades is the so-called establishment of a prosperous society. Amongst the physical evidences which have undergone the lack of preservation is the Pecinan region of Singkawang. This paper discusses the Chinese community in Singkawang in regard to the historical development of Indonesia and preservation strategies of its Pecinan region. The study used descriptive-analytical method with inductive reasoning. The results showed that the Chinese community has contributed to the economic development in the Singkawang region. Thus, the establishment of the Pecinan region can be proposed as a strategy as well as the utilization of cultural heritage preservation of Singkawang.

Keywords: Singkawang history, Chinese community, the archeological record, Singkawang, Pecinan, management of cultural heritage

* Makalah ini dipresentasikan pada Seminar Evaluasi Hasil Penelitian Arkeologi dengan tema "Implementasi Program Penelitian dan Pengembangan Arkeologi Nasional" di Solo pada tanggal 3-7 September 2012.

** Penulis adalah calon peneliti pada Balai Arkeologi Banjarmasin, email: bagoes_balar@yahoo.com 


\section{A. Pendahuluan}

\section{Latar Belakang}

Indonesia merupakan negara yang sudah cukup banyak kehilangan data sejarah akibat pengutamaan sebuah kepentingan yang mengatasnamakan kepentingan masyarakat. Bangunan bersejarah di Indonesia banyak yang dihancurkan untuk digantikan dengan bangunan pertokoan yang berdalih untuk memajukan perekonomian di suatu wilayah. Atau penghancuran suatu data sejarah yang berdalih pada faktor keinginan untuk menghapus kenangan buruk terhadap suatu peristiwa atau ketidaksukaan terhadap golongan tertentu dalam rangka menuliskan sebuah sejarah baru dari keadaan siapa yang menjadi penguasa pada saat ini. Kelompok yang berkuasa saat ini yang akan dominan menentukan cerita sejarah pada masa lalu sehingga menyebabkan bias yang besar terhadap gambaran sejarah.

Salah satu upaya agar bangunan cagar budaya dapat terjaga kelestarian dan keasliannya adalah dengan cara merevitalisasi bangunan tersebut sehingga dapat memberi manfaat pada masyarakat. Saat ini di negaranegara maju, Pecinan, kota lama, dan wisata sejarah merupakan lokasi yang dipertahankan sebagai aset yang sangat berharga guna mendorong perekonomian dari sektor pariwisata dan budaya. Namun tidak sedikit pula negara-negara yang sudah kehilangan banyak peninggalan sejarah akibat dari cara pandang negara yang salah demi peningkatan faktor ekonomi dan unsur politis.

Begitu pula kebudayaan Cina, merupakan sebuah kekayaan bangsa yang tidak ternilai harganya yang harusnya bisa dinikmati anak cucu kita di kemudian hari sebagai sebuah warna-warni budaya Indonesia yang berBhinneka Tunggal Ika sebagai sebuah budaya besar yang ikut serta memberikan sumbangsih terhadap perkembangan bangsa hingga saat sekarang. Dalam bahasan tulisan ini ada dua permasalahan yang perlu dijawab, yaitu apa saja potensi tinggalan arkeologi yang ada di Kota Singkawang dan bagaimana cara melestarikan kawasan Pecinan Singkawang.

Pelestarian bangunan (cagar budaya) secara umum telah menjadi wacana internasional selama beberapa dasawarsa yang lalu, yang dapat dilihat pada beberapa piagam pelestarian, di antaranya The Venice Charter (1964-1965), The Burra Charter (1979), Rekomendasi UNESCO (1976), Piagam Washington (1987), serta The World Herritage Cities Management Guide (1991). Piagam dari International Council of Monuments and Site (ICOMOS) tahun 1981, yaitu Charter for the Conservation of Places of Cultural Significance, Burra, Australia yang dikenal dengan Burra Charter. Dalam Burra Carter (1981) makna pelestarian merupakan suatu proses pengelolaan suatu tempat agar makna kultural yang ada tetap terpelihara dengan baik sesuai situasi dan kondisi setempat. Menurut Piagam Pelestarian Pusaka Indonesia (2003) pelestarian adalah upaya pengelolaan pusaka melalui kegiatan penelitian, perencanaan, perlindungan, pemeliharaan, pemanfaatan, pengawasan, dan/atau pengembangan secara selektif untuk menjaga kesinambungan, keserasian, dan daya dukungnya dalam menjawab dinamika zaman untuk membangun kehidupan bangsa yang lebih berkualitas.

Menurut UU Cagar Budaya No.11 Tahun 2010, pelestarian merupakan upaya dinamis untuk mempertahankan cagar budaya dan nilainya dengan cara melindungi, mengembangkan dan memanfaatkannya. Secara umum, istilah pelestarian merupakan 
proses dalam memelihara, menjaga maupun melindungi sesuatu yang bernilai ekonomi, politik, sosial, dan budaya agar hal tersebut tidak hilang. Pada awalnya, usaha pelestarian hanya menyangkut pengelolaan lingkungan terkait ketersediaan sumber daya alam, namun dalam perkembangannya pelestarian juga mencakup dalam pemeliharaan lingkungan binaan yang salah satunya merupakan bidang arsitektur. Upaya pelestarian bidang arsitektur saat ini telah mencakup kegiatan yang sangat luas, salah satunya lingkup bangunan dan kawasan atau lingkungan (Bani 2004).

\section{Metode Penelitian}

Metode yang digunakan adalah metode deskriptif-analitis, yaitu penelitian yang bertujuan untuk menyusun deskripsi secara sistematis, faktual, serta akurat atas data yang ada dan kemudian dianalisis sehingga didapatkan kesimpulan (Tan 1981, 42). Teknis di lapangannya, yaitu dengan cara melakukan perekaman dan verifikasi kelayakan suatu bangunan atau kawasan hingga dapat dikategorikan sebagai cagar budaya sesuai dengan studi histori dan studi teknis. Penalaran yang digunakan adalah penalaran induktif, yaitu penalaran yang bergerak dari gejala khusus untuk kemudian ditarik kesimpulan secara umum berdasarkan pengamatan sampai dengan penyimpulan, sehingga terbentuk generalisasi empirik (Sukendar 1999, 20).

\section{B. Pembahasan}

\section{Sekilas Sejarah Kota Singkawang}

Jarak Kota Singkawang ke ibukota provinsi di Pontianak adalah $145 \mathrm{~km}$ dan tersedia jalan darat yang menyusur di sepanjang pantai.
Dalam sistem transportasi di Kalimantan Barat, angkutan sungai masih berperan penting untuk menghubungkan suatu daerah dengan daerah lainnya. Bagian utara Kabupaten Sambas berbatasan dengan Negara bagian Serawak Malaysia, sedangkan bagian selatan berbatasan dengan Kabupaten Pontianak. Laut Natuna merupakan batas bagian barat Kabupaten Sambas dan di sebelah timur berbatasan dengan Kabupaten Sanggau dan Pontianak.

Penamaan kota ini muncul dalam beberapa versi menurut bahasa. Dalam versi Melayu dikatakan bahwa nama Singkawang diambil dari nama tanaman 'Tengkawang' yang terdapat di wilayah hutan tropis. Menurut versi Cina, Singkawang berasal dari bahasa Hakka, yaitu San Kheu Young atau dalam bahasa Mandarin Shan (gunung), Kou (mulut sungai), Yang (lautan). Nama Singkawang muncul melalui penafsiran dari para perantau Cina di masa lalu. Lokasi ini terletak di muara Sungai Singkawang dan berlatar belakang gunung, terutama jika dilihat dari arah laut (Poerwanto 2005, 132).

Pada masa penjajahan Belanda, Singkawang adalah salah satu afdeling dari empat buah afdelingen (yang lain adalah afdeling Pontianak, Ketapang, dan Sintang) di lingkungan Westerafdeling van Borneo. Di kala itu Gouvernement van Borneo beribukota di Banjarmasin yang pada saat ini merupakan ibu kota Provinsi Kalimantan Selatan. Selanjutnya, afdeling Singkawang meliputi Sambas, Singkawang, Bengkayang, dan Mempawah.

Dari beberapa catatan sejarah, Singkawang mulai dikenal oleh orang Eropa sejak tahun 1834 yang tercantum dalam buku tulisan George Windsor Earl berjudul The Eastern Seas yang menyebut nama kota ini 
dengan kata 'Sinkawan'. Pada masa itu, Singkawang lebih dikenal sebagai daerah koloni Cina di masa kongsi-kongsi (dalam bahasa Mandarin, istilah kongsi ditulis Gongsi yang artinya bekerjasama). Dalam bahasa Hakka dilafalkan Kung-Sze, dan di Riau serta di Jawa dilafalkan kongsi. Ada pula yang mengartikan istilah tersebut sebagai 'perusahaan (per) dagang (an)', antara lain karena bertujuan mencari keuntungan (Poerwanto 2005, 342- 343). Menurut Wang Tai Ping $(1977,2)$, hampir semua organisasi kemasyarakatan orang Cina pada abad ke-19 Masehi disebut dengan kongsi, termasuk pula organisasi rahasia Hokkian disebut Hui Kuan. Agaknya istilah terakhir ini telah lama digunakan, yaitu sejak abad ke-16 Masehi. Selanjutnya, ada berbagai pembahasan mengenai kongsi, istilah ini antara lain sering digunakan untuk menyebut beberapa kelompok yang saling mengikatkan dirinya guna berbagai tujuan, baik sosial ekonomi maupun politik. Kerjasama di antara para anggotanya diikat oleh suatu loyalitas tertentu. Keanggotaan sebuah kongsi biasanya mencakup suatu lineage, dan biasanya juga mempunyai wilayah kekuasaan tertentu. Penambang emas berkuasa dengan Monterado sebagai pusat kekuasaan para penambang tersebut (dalam tulisan sejarah tersebut nama seseorang bernama Kung She yang dipercaya memiliki pengaruh).

Catatan lainnya juga didapat dari salah satu tulisan G.F De Bruijn yang termuat dalam De Volken Van Nederlandsch Indie (1920) berjudul De Maleiers yang terjemahannya berbunyi : "...beberapa puluh mil di sebelah selatan kerajaan (Sambas) dibangun sebuah kota yang dimaksud sebagai kota pemerintahan Belanda" (dalam Saad 2008).

Dilihat dari sejarahnya, Singkawang merupakan bagian dari Kerajaan Sambas, tetapi pusat kekuasaannya dan pusat kegiatan belum sampai menjamah Singkawang. Hal ini disebabkan masih dominannya kuasa ekonomi di tangan kongsi-kongsi Monterado. Sebaliknya, kekuasaan raja-raja Sambas masih mampu mengatasi berbagai pemberontakan termasuk bantuan yang diberikan Kompeni Belanda dengan mengirimkan Overste Zorg. Namun dengan berbagai kejadian itu, Kerajaan Sambas merasa belum perlu memanfaatkan Singkawang terutama pelabuhannya karena Sambas sendiri memiliki pelabuhan yang cukup baik dan memenuhi syarat pada masa itu.

Setelah orang Cina bermukim di wilayah pesisir bagian barat Pulau Kalimantan, deposit emas di pedalaman tampaknya merupakan daya tarik utama yang menyebabkan terjadinya pergeseran konsentrasi tempat tinggal mereka. Orang Cina yang semula bermukim di daerah pesisir, bergerak menuju ke pedalaman. Turunnya izin dari penguasa Melayu kepada orang Cina untuk mengusahakan penambangan emas, menyebabkan daerah pedalaman semakin banyak didatangi orang Cina. Berikutnya muncullah perkampungan Cina di daerah pertambangan. Berdasarkan kenyataan ini, seringkali dikatakan bahwa penetrasi orang Cina ke Kalimantan Barat baru terjadi pada tahun 1770.

Sebenarnya keberadaan deposit emas di pedalaman sudah lama diketahui. Tambang emas itu biasanya dieksplorasi orang Dayak atas izin dari penguasa Melayu. Akan tetapi, pada tahun 1740 Panembahan Mempawah mengundang sekelompok orang Cina dari Brunei untuk menambang emas di Sungai Duri. Sejak saat itu, pertambangan emas meluas ke berbagai pelosok di Mempawah, misalnya ke Minawang, Sinman, dan Mandor. 
Kedatangan orang Cina ke Kalimantan Barat dalam jumlah besar baru berlangsung sekitar tahun 1750, ketika Sultan Sambas memberi izin kepada mereka untuk menambang emas di Monterado. Pemukiman mereka di sana berkembang amat pesat, terutama setelah dibuka tambang baru di Mandor pada tahun 1770 (Jakson 1970, 22).

\section{Beberapa Tinggalan Arkeologis di Kawasan Pecinan Kota Cina Singkawang}

\section{a. Klenteng-klenteng Tua}

Jika kita berjalan di sekitar Kota Singkawang maka pandangan mata kita tertuju pada bangunan bercat merah menyala yang terletak di persimpangan-persimpangan jalan. Masyarakat Singkawang menyebutnya dengan bangunan Pe Kong. Pe Kong berasal dari kata Toh Pe Kong yang berarti Dewa Bumi. Pada kota-kota besar di Indonesia lainnya, keberadaan klenteng mungkin baru terlihat setelah diakuinya agama Konghucu di Indonesia. Namun berbeda dengan klentengklenteng di Singkawang, usianya sudah berkisar antara seratus hingga tiga ratus tahun yang lalu dan tidak pernah ditinggalkan oleh penganutnya. Lokasi klenteng tersebut tidak hanya di pusat Kota Singkawang, tetapi menyebar dari pesisir pantai di daerah perbukitan dan di perkampungan di sekitar Kota Singkawang.

\section{b. Bangunan Peninggalan Masa Kolonial Belanda}

(1). Landraad Singkawang

Merupakan bangunan peninggalan Belanda yang dulunya berfungsi sebagai kantor pengadilan dan penjara pertama yang dibangun di Singkawang. Saat ini, bangunan yang masih berdiri kokoh ini difungsikan sebagai salah satu kantor pemerintah Kota
Singkawang. Bangunan ini didirikan pada tahun 1920 yang letaknya berada di Jalan Merdeka Singkawang, Kelurahan Melayu, Kecamatan Singkawang Barat.di sekitar Kota Singkawang.

(2). Borsumay (Borneo Sumatera Maatschappij) Singkawang

Merupakan bangunan yang digunakan Belanda untuk menimbun hasil dagang Belanda pada saat itu. Keadaan bangunan ini sudah sangat memprihatinkan dan sangat tidak layak untuk dipergunakan lagi.

(3). Rumah Petinggi Belanda

Bangunan ini didirikan pada 1912 yang letaknya berada di Jalan Perwira Singkawang, Kelurahan Sekip Lama, Kecamatan Singkawang Tengah. Dahulunya bangunan ini merupakan rumah tinggal para perwira Belanda, dan hingga saat ini masih juga difungsikan sebagai rumah tinggal para anggota TNI Kodim Singkawang.

(4). Water Tourn Singkawang

Bangunan tandon air yang didirikan oleh pemerintah Belanda pada 1927 digunakan untuk memenuhi kebutuhan air bersih masyarakat Kota Singkawang hingga saat ini. Bangunan ini terbuat dari plat besi yang berupa tong dengan ukuran besar yang berdiri di atas tiang besi baja yang tingginya kurang lebih 20 meter.

(5). Algemene Nederland Indie Maatschappij

Bangunan ini didirikan oleh Belanda pada 1927, dan dipergunakan sebagai kantor kongsi dagang milik Belanda. Bangunan ini terletak di Jalan Jenderal Sudirman Singkawang, Kelurahan Condong, Kecamatan Singkawang Tengah, dan saat ini digunakan oleh PLN (Perusahaan Listrik Negara) Singkawang sebagai gudang mesin. 


\section{c. Dragon Kiln}

Pada awal abad ke-20, muncul pengrajin keramik di Singkawang. Kehadiran teknologi keramik di Singkawang ini, bukan saja hasil dari transformasi ide, tetapi sekaligus disertai pindahnya pengrajin, yaitu imigran Cina yang membawa pengetahuan dan ketrampilan. keramik Singkawang sebagai produk yang ditangani secara tradisional, ditandai oleh penggunaan tungku tertutup yang mampu menghimpun panas sampai 1200 derajat celcius. Bahan yang digunakan adalah kaolin dan tanah liat, yang menghasilkan keramik dengan kualitas sebaik keramik yang dikembangkan pada abad sebelumnya di Asia daratan. Keramik Singkawang menjadi salah satu jenis teknologi tradisional yang kini masih berproduksi. Kasus seperti ini sudah tidak ada duanya, bahkan di Cina sendiri yang dipandang sebagai pionir di bidang ini sudah tidak lagi melakukan cara tradisional dalam membuat barang dari keramik (Wibisono 1990, 136137).

Pembakaran merupakan saat paling menentukan dalam pembuatan keramik. Tidak jarang keramik indah yang telah dikerjakan rusak di tungku pembakaran. Perlengkapan utama pembakaran adalah tungku tradisional yang disebut tungku naga (Dragon Kiln/ Long Yao) oleh orang Cina dan orang Singkawang sekarang. Bentuknya seperti naga, panjangnya 30-38 meter, lantainya melereng semakin menyempit sampai ke kepalanya, ekornya merupakan cerobong asap, lebarnya $150 \mathrm{~cm}$ dan badannya merupakan cerobong setinggi $1-2$ meter, lebar $182 \mathrm{~cm}$, kepala berbentuk kubah kecil melingkar lebar $127 \mathrm{~cm}$ dengan 4 lubang tempat menyulut api kayu. Tungku mempunyai dua pintu, yaitu di bagian depan setinggi 127 $\mathrm{cm}$, lebar $77 \mathrm{~cm}$, dan di bagian belakang tinggi $135 \mathrm{~cm}$, lebar $97 \mathrm{~cm}$. Pintu-pintu ini berfungsi untuk keluar masuk keramik yang akan dibakar atau yang sudah selesai dibakar. Pada bagian badan tungku terdapat banyak jendela dengan tinggi $24 \mathrm{~cm}$ dan lebar $8 \mathrm{~cm}$ yang berfungsi untuk memasukkan api. Lama pembakaran 24 jam, dengan bahan bakar kayu karet. Tungku ini dibuat dari bata tahan api. Jenis tungku yang digunakan merupakan tungku yang pertama kali digunakan oleh pengrajin Cina pada abad ke-10 hingga akhir abad ke-19 Masehi (Wibisono 1990, 136-141). Sejauh informasi yang dapat dilacak, tungku keramik di Singkawang, Kalimantan Barat sudah ada sejak pertengahan abad ke-20. Berdirinya pabrik keramik Singkawang, tampaknya serupa dengan kasus penyebaran pengetahuan dan pabrik dari Cina. Para imigran Cina memprakarsainya, mereka membawa pengetahuan, ketrampilan dan tradisi dari tempat asalnya. Salah satu di antaranya adalah tungku pembakarannya.

\section{d. Rumah Tua dengan Arsitektur Cina}

Salah satu bangunan rumah yang terdapat di Kota Singkawang adalah bangunan rumah keluarga Tjhia Hiap Seng (Marga Xia). Bangunan tradisional Cina yang memiliki corak kombinasi budaya timur dan barat. Sebagian besar bangunan adalah kayu ulin (kayu belian). Rumah besar ini memiliki dua ruangan besar di bagian depan dan belakang yang penuh dengan ornamen dan ukiran maupun kaligrafi berwarna emas di setiap ambang pintu.

Dalam ruangan depan tersusun satu set meja kursi mewah dengan ukiran dan tatanan nirmala ala Cina, untuk menerima tamu pejabat setempat dan masyarakat maupun pengusaha. 


\section{Bentuk Pelestarian Kawasan Pecinan Singkawang}

1. Menjadikan Kawasan Pecinan Singkawang sebagai Kawasan Cagar Budaya

Manfaat kegiatan preservasi terhadap peninggalan arkeologi dan budaya di kawasan kota tua Singkawang adalah melestarikan lingkungan masa lalu yang akan memperkaya pengalaman visual, menyalurkan hasrat kesinambungan, memberi tautan bermakna dengan masa lampau, dan memberikan pilihan untuk tetap tinggal dan bekerja di dalam bangunan maupun lingkungan lama tersebut. Di tengah perubahan dan pertumbuhan yang pesat seperti sekarang ini, lingkungan lama akan menawarkan suasana permanen yang menyegarkan. Teknologi pembangunan yang berorientasi pada nilai-nilai ekonomis di atas lahan berskala besar ternyata berakhir dengan keseragaman yang membosankan. Upayaupaya untuk mempertahankan bagian kota yang dibangun dengan skala akrab akan membantu hadirnya sense of place, identitas diri, dan suasana kontras. Kota dan lingkungan lama adalah salah satu aset terbesar dalam industri wisata internasional, sehingga perlu dilestarikan. Upaya preservasi dan konservasi merupakan salah satu upaya generasi masa kini untuk dapat melindungi dan menyampaikan warisan berharga kepada generasi mendatang. Preservasi dan konservasi akan membuka kemungkinan bagi setiap manusia untuk memperoleh kenyamanan psikologi yang sangat diperlukannya untuk dapat menyentuh, melihat, dan merasakan bukti fisik suatu tempat di dalam tradisinya dan upaya-upaya pelaksanaan preservasi dan konservasi akan membantu terpeliharanya warisan arsitektur, yang dapat menjadi catatan sejarah masa lampau dan melambangkan keabadian serta kesinambungan, yang berbeda dengan keterbatasan kehidupan manusia.

Mills (1994) mengklasifikasikan manfaat pelestarian bangunan dalam tiga bagian, yaitu:

a. Keuntungan dari sisi ekonomi. Pada prinsipnya, pelestarian memberikan keuntungan dalam hal waktu, karena menghemat antara setengah sampai tiga-perempat waktu yang digunakan untuk demolisi dan konstruksi yang baru, sehingga diikuti oleh keuntungan ekonomis, yakni masa pengembangan yang lebih singkat mengurangi biaya pembiayaan proyek dan juga mengurangi efek inflasi pada biaya bangunan, dan klien memiliki bangunan dalam jangka waktu yang lebih cepat, dengan demikian dapat mulai menerima pemasukan dari penggunaan bangunan lebih cepat. Selain itu, biaya untuk mengubah/ merehabilitasi bangunan umumnya sekitar separuh dari biaya konstruksi bangunan, karena banyak elemen bangunan yang sudah ada sebelumnya;

b. Keuntungan dari lingkungan. Bangunan yang mempunyai nilai sejarah atau arsitektural tinggi sebaiknya dijaga, mengingat kontribusinya untuk keramahtamahan visual bagi kawasan sekitar, kebudayaan, atau interpretasi sejarah. Pelestarian kawasan yang menarik jika dikombinasikan dengan rehabilitasi bangunan tua untuk mengakomodasi fungsi yang modern terkadang bisa diartikan sebagai keuntungan finansial. Konteks fisik 
suatu bangunan yang telah dilestarikan sama pentingnya dengan nilai fisik bangunan tersebut. Jika suatu bangunan berdiri dekat dengan bangunan tua lain yang menarik secara arsitektural, daya tarik dan nilainya akan meningkat. Pelestarian bangunan tersebut akan nampak, dan idealnya akan memperkuat karakter dan integritas arsitekturalnya. Dalam konteks yang lebih luas, bangunan dapat dilihat sebagai sumber daya yang potensial untuk digunakan kembali (re-use) daripada sumber daya yang dapat tergantikan;

c. Keuntungan dari sisi sosial. Menciptakan suatu komunitas yang baru adalah sebuah proses yang rumit dan tidak bisa tercapai seperti yang diharapkan oleh arsitek dan perancang kota.

Menurut Shrivani (1985), pelestarian pada suatu kawasan maupun bangunan dapat memberikan beberapa manfaat antara lain:

a. Manfaat kebudayaan, yaitu sumbersumber sejarah yang dilestarikan dapat menjadi sumber pendidikan dan memperkaya estetika;

b. Manfaat ekonomi, yaitu adanya peningkatan nilai properti, peningkatan pada penjualan ritel dan sewa komersil, penanggulangan biaya-biaya relokasi dan peningkatan pada penerima pajak serta pendapatan dari sektor pariwisata;

c. Manfaat sosial dan perencanaan, karena upaya pelestarian dapat menjadi kekuatan yang tepat dalam memulihkan kepercayaan masyarakat.
Meskipun kegiatan pelestarian bangunan maupun kawasan bersejarah masih kurang dipahami sebagian masyarakat di Indonesia, tetapi dengan banyaknya manfaat yang didapat melalui upaya pelestarian sepatutnya hal ini mulai dikembangkan dalam pola pikir masyarakat agar masyarakat suatu kota maupun kawasan yang memiliki potensi untuk dilestarikan dapat ikut berperan serta dalam upaya pelestarian bangunan maupun kawasan.

\section{Menjadikan Kawasan Pemukiman Cina Singkawang sebagai Pecinan}

Menciptakan suatu wadah kegiatan yang menampung segala kegiatan yang terjadi di suatu kawasan wisata, khususnya wisata budaya yang mampu memberikan rasa aman, nyaman, rekreatif dan atraktif bagi para pengunjung merupakan suatu langkah agar suatu kawasan memiliki daya tarik dan memiliki nilai lebih agar keberadaannya selalu dipertahankan. Memberikan suatu wahana bagi pengunjung yang ingin menikmati situs budaya yang mempunyai nilai-nilai historis serta menikmati atraksi ritual keagamaan seperti pada saat pelaksanaan upacara Imlek dan Cap Gomeh serta suasana kota yang memberikan suasana seolah-olah kita berada di daratan Cina.

\section{Proses Penanganan Kawasan}

a. Pengembangan/Redevelopment Kawasan

Upaya pengembangan/redevelopment dilakukan untuk mengembangkan kondisi kawasan Kampung Pecinan di pusat Kota Singkawang, yaitu di sekitar Klenteng Bumi Raya sebagai wisata budaya. Fokus utama dalam pengembangan aktivitas baru pada kawasan adalah penyelenggaraan kegiatan 
wisata kuliner dan belanja yang juga diramaikan dengan atraksi budaya khas Cina seperti barongsai, tarian, dan lain-lain pada malam hari di sekitar kawasan wisata kuliner Pasar Hongkong. Makanan tradisional orang Cina di sepanjang Pasar Hongkong ini merupakan daya tarik tersendiri bagi keunikan yang dimiliki oleh Kota Singkawang dengan budaya yang masih asli menyerupai budaya asalnya di daratan Cina.

\section{b. Konservasi}

Dilakukan konservasi pada bangunanbangunan yang berada di Kota Singkawang yang dinilai memenuhi studi kelayakan, studi historis, dan studi teknis agar keberadaan serta kelestariannya dapat lebih terkontrol. Perlakuan yang khusus memang diperlukan untuk bangunan-bangunan yang memiliki nilai sejarah ini, mengingat usianya yang sudah cukup tua maka keaslian bahan dan bentuk dari bangunan ini sangat perlu diberi perhatian dan perawatan lebih menurut kaidah-kaidah keilmuan arkeolgi.

\section{c. Peningkatan Kualitas Bangunan Pendukung dan Lingkungan}

Bangunan dan lingkungan pada kawasan studi terdapat berbagai macam kualitas. Bangunan yang kualitasnya masih kurang, perlu ditingkatkan untuk pengembangan jangka panjang nantinya agar keberadaannya dapat bertahan lama. Penggunaan fasilitas ini nantinya tidak hanya dari satu lapisan ekonomi masyarakat, tetapi akan lebih variatif.

\section{d. Faktor Pendukung Pengembangan Kawasan Pecinan Kota Singkawang}

Potensi alam yang sangat mendukung, namun hingga saat ini belum dimanfaatkan dan dikembangkan untuk menunjang kegiatan pariwisata, sehingga diperlukan perencanaan kawasan yang terpadu. Keberadaan Kota Singkawang yang berada di pesisir Kalimantan Barat memiliki pantai yang sangat bagus untuk dikunjungi, pasirnya yang putih dan airnya yang tenang membuat pantai-pantai di Kota Singkawang ini sangat cocok untuk digunakan sebagai tempat untuk berlibur. Selain pantai, Singkawang juga memiliki wisata alam seperti kawasan pegunungan di kawasan Roban, Bukit Sijangkung, dan Bukit Sari.

Potensi keagamaan yang selama ini dijadikan kegiatan ritual kurang mendapat perhatian penuh, baik dari fasilitas-fasilitas yang tersedia maupun kegiatan pendukung yang memberikan daya tarik tersendiri.

\section{Penutup}

\section{Kesimpulan}

Banyaknya peninggalan arkeologi di Kota Singkawang membuat kita harus memikirkan sebuah strategi bagaimana peninggalan tersebut dapat dilestarikan dan juga memberi manfaat bagi si pemegang hak atas tinggalan tersebut serta masyarakat dan kemajuan daerah. Salah satu cara untuk melestarikan dan memanfaatkan tinggalan tersebut adalah dengan melakukan revitalisasi bangunan cagar budaya tersebut dengan memperhatikan kaidah-kaidah ilmu arkeologi sehingga kawasan tersebut dapat bermanfaat dan terlestarikan

Salah satu produk dari revitalisasi kawasan pecinan lama adalah dengan membuat sebuah pecinan dengan konsep kembali ke masa lalu. Budaya etnis Cina yang berkembang di Kalimantan Barat dan khususnya di Kota Singkawang tumbuh dan berkembang secara difusi. Ini merupakan nilai lebih dari kawasan kota lama Singkawang untuk menjadi sebuah Pecinan, sebab 
pendukung budaya dari tinggalan tersebut masih ada dan masih melangsungkan aktifitas budayanya secara turun menurun, sama dengan budaya aslinya di daratan Cina.

Dalam pembuatan Pecinan tersebut arkeolog memiliki peran dalam upaya pelestarian dan pemanfaatan bangunan tersebut dengan berpegang pada arkeologi untuk publik. Secara tidak langsung maka kelangsungan tinggalan-tinggalan arkeologi di Kota Singkawang tetap terjaga keberadaannya karena tinggalan tersebut kembali memiliki nilai yang memberi manfaat bagi kelangsungan masyarakat pendukungnya saat ini.

\section{Rekomendasi}

Tinggalan arkeologi di Kota Singkawang dan sekitarnya harus mendapatkan perhatian lebih dari pemerintah pusat dan daerah demi kelestariannya. Jumlahnya yang kian hari semakin berkurang akibat tergerus pembangunan yang membabi buta dengan alasan faktor ekonomi atau kepentingan masyarakat mengharuskan semua pihak memikirkan hal tersebut.

Salah satu cara yang disarankan adalah dengan membuat sebuah model pelestarian yang memberikan nilai lebih dari sebuah bangunan dalam sebuah kawasan yang terpadu. Dengan manajemen yang matang serta sistem pengelolaan yang benar-benar untuk kepentingan masyarakat yang tetap mengutamakan keutuhan dan keaslian bangunan. 


\section{Referensi}

Bani, Noor Muhammad. 2004. Model pelestarian arsitektur berbasis teknologi informasi studi kasus arsitektur tradisional suku Banjar. Dimensi Jurnal Teknik Arsitektur. Surabaya: Universitas Kristen Petra.

Bingling, Yuan. 2000. Chinese democracies. A study of the kongsis of West Borneo (1776-1884). Netherlands: Research School of Asian, African, and Amerindian Studies Universitiet Leiden.

Budiharjo, Eko. 1985. Arsitektur dan pembangunan kota di Indonesia. Bandung : Alumni

Jackson, James C. 1970. Chinese in the West Borneo goldfield: a study in cultural geography. London: University of Hull.

Mills, E. 1994. Building maintenance and preservation: a guide for design and management. Oxford: ButterworthHeinemann
Poerwanto, Hari. 2005. Orang Cina Khek dari Singkawang. Depok: Komunitas Bambu.

Saad, Munawar M. 2008. Sejarah berdirinya pemerintahan Kota Singkawang. Pontianak: STAIN Pontianak Pers.

Shirvani, H. 1985. Urban design process. New York: Van Nostrand Remhold.

Sukendar, Haris dkk. 1999. Metode penelitian arkeologi. Jakarta: Departemen Pendidikan Nasional.

Tan, Melly G. 1981. Masalah perencanaan penelitian. Dalam Metode-metode penelitian arkeologi. Jakarta: Gramedia.

Wang, Tai Peng. 1977. The origins of Chinese kongsi: with special reference to West Borneo. Canberra: Australia National University.

Wibisono, Naniek H 1990. Keramik Singkawang: sisa-sisa teknologi kuno. Dalam Saraswati Esai-esai Arkeologi (1). 